\title{
PENERAPAN MODEL PEMBELAJARAN KOOPERATIF STAD UNTUK MENINGKATKANPRESTASI BELAJAR IPA
}

\author{
Oleh : \\ Nyoman Warta \\ Email :warta_n@ymail.com
}

\begin{abstract}
ABSTRAK
Penelitian ini bertujuan untuk meningkatkan prestasi belajar IPA siswa kelas IX-B SMP Negeri 4 Banjar melalui penerapkan model pembelajaran kooperatif STAD (Student Team Achievement Divison). Penelitian ini dirancang dalam dua siklus. Rancangan tiap-tiap siklus terdiri dari empat tahapan yaitu; perencanaan, tindakan, dan refleksi. Subjek penelitian adalah siswa kelas IX-B SMP Negeri 4 Banjar semester ganjil tahun pelajaran 2015/2016 berjumlah 27 orang. Pada pembelajaran prasiklus siswa yang mencapai ketuntasan $66,67 \%$ dan siswa yang tidak tuntas 33,33\%. Dataprestasi belajar IPAmelaluites prestasi belajar IPA pilihan ganda dan isian. Data prestasi belajar IPAdianalisis secara deskriptif dan dinarasikan secara kualitatif. Hasil penelitian pada siklus-1 adalah: (1) nilai terendah 60,00 dan nilai tertinggi 90,00, (2) rata-rata kelas76,30, dan (3) siswa yang tuntas $81,48 \%$ (belum memenuhi ketuntasan klasikal $\geq 85 \%$ berdasarkan KKM 70,00. Hasil penelitian pada siklus-2: (1) nilai terendah 60,00 dan nilai tertinggi 95,00 , (2) rata-rata kelas77,78, dan (3) siswa yang tuntas $88,89 \%$ (memenuhi ketuntasan klasikal $\geq 85 \%$ berdasarkan KKM 70,00). Berdasarkan analisishasil penelitian dari siklus-1 ke siklus-2 dapat disimpulkan bahwa, penerapan model pembelajaran kooperatif STAD dapat meningkatkan prestasi belajar IPAsiswa kelas IX-B SMP Negeri 4 Banjar semester ganjil tahun pelajaran 2015/2016.
\end{abstract}

Kata kunci: penelitian tindakan kelas, model kooperatif STAD, prestasi belajar IPA

\begin{abstract}
This study aims to improve the science learning achievement of science students in class IX-B of SMP Negeri 4 Banjar through implementing the STAD (Student Team Achievement Divison) cooperative learning model. This research was designed in two cycles. The design of each cycle consists of four stages, namely; planning, action and reflection. The subjects of the study were students of class IX-B Banjar Middle School 4 in the odd semester of 2015/2016 school year totaling 27 people. In pre-cycle learning students who achieved completeness $66.67 \%$ and incomplete students $33.33 \%$. Data on Natural Sciences learning achievement through a multiple-choice science and learning achievement test. Data on science learning achievements were analyzed descriptively and narrated qualitatively. The results of the research in cycle-1 are: (1) the lowest value is

Penerapan Model Pembelajaran Kooperatif StadUntuk


60.00 and the highest value is 90.00 , (2) the average class is 76.30, and (3) the students complete $81.48 \%$ (not yet fulfilling the classical completeness $\geq 85 \%$ based on KKM 70.00 The results of the research on cycle 2: (1) the lowest value is 60.00 and the highest value is 95.00 , (2) the average class is 77.78 , and (3) the students are complete $8889 \%$ (fulfilling classical completeness $\geq 85 \%$ based on KKM 70.00) Based on the analysis of research results from cycle 1 to cycle 2 it can be concluded that, the application of STAD cooperative learning model can improve science learning achievement of students of class IX-B of Public Middle School 4 Banjar odd semester 2015/2016 school year.

Keywords: STAD cooperative model, learning outcomes

\section{PENDAHULUAN}

Kegiatan belajar mengajar merupakan suatu kegiatan interaksi multi arah, siswa dengan siswa, dan siswa dengan lingkungannya. Interaksi dan hubungan antara guru dan siswa merupakan syarat utama bagi berlangsungnya proses pembelajaran. (Usman, 2005 dalam Sucipta,dkk., 2014: 4). Kegiatan pembelajaran berlangsung efektif jika pemilihan dan penggunaan pendekatan atau model pembelajaran hendaknya sesuai dengan karakteristik kompetensi yang dibelajarkan dan tingkat perkembangan kognitif siswa. Hal senada dikemukakan oleh Sumantri (2015: 154) yang mengemukakan bahwa, dalam memilih suatu pendekatan atau model pembelajaran hendaknya disesuaikan dengan tingkat perkembangan kognitif siswa dan juga mempertimbangkan karakteristik siswa.

Tujuan pembelajaran tercapai secara optimal, jika kegiatan pembelajaran berpusat pada siswa (student's centred) dan siswa dalam belajarkan diarahkan terjadi proses berpikir dan berbuat (to thinking and to doing learning). Joyce, 1991 (Trianto, 2010 : 134) menyatakan bahwa, inti dari berpikir yang baik adalah kemampuan untuk memecahkan masalah dan dasar pemecahan masalah adalah kemampuan untuk belajar dalam situasi berpikir. Dengan demikian, hal ini dapat diimplementasikan bahwa kepada siswa hendaknya diajarkan bagaimana belajar yang meliputi apa yang diajarkan, bagaimana hal itu diajarkan, jenis kondisi belajar, dan memperoleh pandangan baru.Realitanya dalam membelajarkan standar kompetensi "Memahami berbagai sistem dalam kehidupan manusia" di 
kelas IX-B SMP Negeri 4 Banjar semester ganjil tahun pelajaran 2015/2016 masih didominasi metode ceramah. Kegiatan pembelajaran dilakukan secara klasikal dengan aturan-aturan tertentu, yaitu; siswa diminta memperhatikan dan mencatat penjelasan guru, dan mengerjakan tugas-tugas mandiri yang dibebankan pada masing-masing siswa. Belum terjadi kegiatan eksplorasi informasi atau materi secara kelompok sesuai kebutuhan belajarnya, siswa cenderung belajar secara individual yang memunculkan kesenjangan pencapaian prestasi belajar IPA antar siswa. Demikian juga pada tahap elaborasi dan konfirmasi masih didominasi oleh guru, siswa masih diposisikan sebagai penerima pengetahuan sehingga siswa dalam hal ini dijadikan objek pembelajaran.

Dampak kegiatan pembelajaran yang demikian adalah penguasaan kompetensi atau materi yang dibelajarkan hanya diterima oleh memori jangka pendek (short term memory) sehingga masih bersifat labil serta mudah dilupakan. Hal tersebut terindikasi dari pencapai ketuntasan klasikal 66,67\% atau 18 siswa dari 27 siswa kelas IX-B SMP Negeri 4 Banjar semester ganjil tahun pelajaran 2015/2016 berdasarkan Kriteria Ketuntasan Minimal (KKM) 70,00.Refleksi yang dilakukan terhadap kegiatan belajar prasiklus, terindikasi permasalahanpermasalahan dalam pembelajaran IPA di kelas IX-B SMP Negeri 4 Banjar semester ganjil tahun pelajaran 2015/2016 sebagai berikut; (1) siswa cenderung hanya mendengar dan mencatat penjelasan guru (pembelajaran berpusat pada guru) karena semua infomasi terkait kompetensi atau materi yang dibelajarkan bersumber dari guru, (2) minimnya upaya siswa melakukan eksplorasi terkait kompetensi yang dibelajarkan, (3) kegiatan belajar siswa bersifat individual tanpa adanya kegiatan diskusi, dan (4) minimnya upaya siswa untuk menyelesaikan tugas-tugas yang diberikan. Berdasarkan identifikasi permasalahan pembelajaran tersebut, dapat dikelompokkkan menjadi dua permasalahan pokok, yaitu siswa dan guru. Guru dalam kegiatan pembelajaran cenderung menjadikan siswa sebagai objek pembelajaran sehingga membatasi kreativitas yang dimiliki masingmasing siswa. Motivasi belajar siswa menjadi kurang karena belum memahami manfaat kompetensi yang dipelajarinya karena kurang mengkaitkan antara pengetahuan yang dimiliki dengan pengetahuan baru yang dipelajarinya. 
Berdasarkan refleksi terhadap pembelajaran prasiklus, dilakukan inovasi pembelajaran dengan menerapkan model pembelajaran kooperatif STAD (Student Team Achievement Divison). Model pembelajaran kooperatif dianggap ideal dalam meningkatkan prestasi belajar IPA yang baik. Pembelajaran kooperatif STADadalah salah satu jenis dari pembelajaran kooperatif dengan menggunakan kelompok-kelompok kecil dengan jumlah anggota tiap kelompok 45 orang siswa secara heterogen. Diawali dengan penyampaian tujuan pembelajaran, penyampaian materi, kegiatan kelompok, kuis dan penghargaan kelompok. Model kooperatif STAD merupakan salah satu rumpun model pembelajaran sosial yang melatih keterampilan sosial sebagai dampak pengiringnya disamping mampu memfasilitasi kegiatan pembelajaran melalui proses berpikir dan berbuat untuk meningkatkan kemampuan akademik (Ibrahim, dkk., 2000 : 17). Lebih lanjut, Riyanto (2012 : 265) mengemukakan bahwa, dalam pembelajaran kooperatif terjadi interaksi yang mampu menumbuhkan rasa kebersamaan antara sesama anggota kelompok serta terjadi saling ketergantungan positif antar individu. Pembelajaran kooperatif STAD, siswa dalam belajar terjadi multi komunikasi atau komunikasi banyak arah (komunikasi sebagai transaksi).

Ibrahim, dkk., 2000 (Trianto, 2010 : 54) menguraikan sintaks pembelajaran kooperatif STAD sebagai berikut; (a) menyampaikan tujuan dan memotivasi siswa, (b) menyajikan/menyampaikan informasi, (c) mengorganisasikan siswa dalam kelompok belajar, (d) membimbing kegiatan belajar kelompok, (e) evaluasi, dan (f) memberikan penghargaan. Kegiatan belajar kelompok, siswa akan melakukan komunikasi secara efektif antar anggota kelompok dan adanya penghargaan kelompok akan mampu memotivasi siswa untuk melakukan kegiatan belajar secara optimal yang pada akhirnya diharapkan berdampak pada peningkatan prestasi belajar IPA siswa.Model pembelajaran kooperatif adalah salah satu model pembelajaran yang dapat mewujudkan kegiatan pembelajaran yang berpusat pada siswa untuk semua mata pelajaran dan berbagai usia (Trianto, $2010: 67$ ). 
Berdasarkan latar belakang masalah penelitian yang diuraikan di atas, dirumuskan permasalahan penelitian, yaitu "Apakah penerapan model pembelajaran kooperatif STAD (Student Team Achievement Divison) dapat meningkatkan prestasi belajar IPA IPA siswa kelas IX-B SMP Negeri 4 Banjar semester ganjil tahun pelajaran 2015/2016?".

\section{METODE PENELITIAN}

Penelitian yang dilaksanakan adalah Penelitian Tindakan Kelas (Classroom Action Research). Prosedur penelitian tindakan ini mengadopsi prosedur yang dikemukakan oleh Arikuto, dkk. (2010: 16) sebagai berikut.

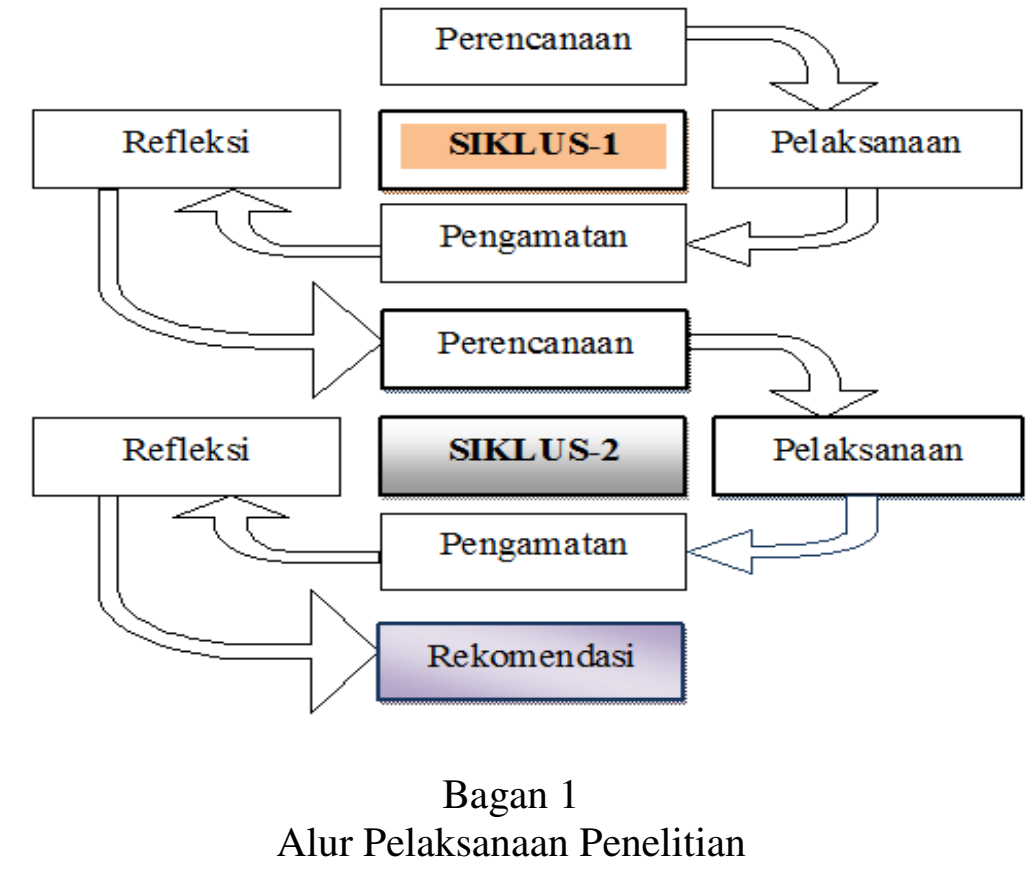

Prosedur pelaksanaan penelitian pada tahap pertama yaitu perencanaan dengan rincian kegiatan; (a) menyusun Rencana Pelaksanaan Pembelajaran (RPP) dengan mengimplementasikan model pembelajaran kooperatif STAD, (b) menyusun Lembar Kerja Siswa (LKS). LKS yang disusun sesuai dengan topik/subtopik yang dibelajarkan setiap pertemuan (tatap muka), (c) menyusun tes prestasi belajar IPA sebanyak lima belas soal terdiri dari sepuluh soal berbentuk pilihan ganda/objektif dan lima soal berbentuk isian, (d) membentuk kelompok 
belajar heterogen berdasarkan jenis kelamin dan kemampuan akademik, dan (e) melatih siswa keterampilan belajar kooperatif STAD. Tahap kedua yaitu tindakan dengan tahapan; (a) menyampaikan tujuan pembelajaran dan memotivasi siswa untuk belajar, (b) memberikan kuis awal untuk mendapatkan skor awal, (c) menyampaikan materi pembelajaran terkait kompetensi yang dibelajarkan, (d) mengorganisasikan belajar siswa dalam kelompok belajarnya, (e) membagikan Lembar Kerja Siswa (LKS) kepada masing-masing kelompok, (f) memfasilitasi kegiatan belajar kelompok, baik dalam melakukan kegiatan belajar kelompok, presentasi tugas kelompok, maupun diskusi kelas, (g) memberikan kuis akhir, dan (h) menghitung skor perkembangan belajar siswa dan memberikan penghargaan kerja kelompok.

Tahap ketiga adalah observasi dan penilaian. Observasi difokuskan terhadap kegiatan belajar siswa sesuai tahapan pembelajaran kooperatif STAD untuk menemukan kesulitan-kesulitan belajar yang dihadapi siswa sehingga bantuan belajar yang diberikan sesuai dengan kebutuhan belajarnya. Pengamatan atau observasi dilakukan terhadap kegiatan belajar siswa baik kegiatan belajar individual maupun kelompok selama kegiatan belajar berlangsung. Pada akhir masing-masing siklus dilakukan penilaian untuk mendapatkan data perkembangan belajar siswa terkait materi yang dibelajarkan.Tahap keempat yaitu refleksi, dilakukan setiap akhir siklus. Sebagai dasar refleksi adalah prestasi belajar IPA siswa terkait materi yang telah dibelajarkan. Hasil refleksi digunakan sebagai acuan untuk: (1) memberikan remedi bagi siswa yang belum tuntas dan memberikan pengayaan bagi siswa yang sudah tuntas, dan (2) perbaikan perencanaan dan pembelajaran pada siklus-2. Selanjutnya hasil refleksi pada siklus-2 digunakan sebagai bahan remedi, pengayaan dan rekomendasi terhadap keberlanjutan pembelajaran melalui penerapan model pembelajaran kooperatif STAD di SMP Negeri 4 Banjar.

Penelitian Tindakan Kelas ini dirancang dalam dua siklus. Siklus-1 dilaksanakan empat kali pertemuan tatap muka pembelajaran dan satu kali tatap muka tes prestasi belajar IPA. Siklus-2 dilaksanakan tiga kali pertemuan tatap muka pembelajaran dan satu kali tatap muka tes prestasi belajar IPA. Masing- 
masing siklus dengan tahapan kegiatan; (1) perencanaan (planning), (2) tindakan (acting), (3) pengamatan dan penilaian (observing and evaluating), dan (4) refleksi (reflecting). Subjek penelitian adalah siswa kelas IX-B SMP Negeri 4 Banjar semester ganjil tahun pelajaran 2015/2016 berjumlah dua puluh tujuh orang terdiri atas tiga belas orang laki-laki dan empat belas orang perempuan.

Teknik yang digunakan untuk mengumpulkan dataprestasi belajar IPA yaitu menggunakan pilihan ganda (tes objektif) sepuluh belas soal dan isian lima soal sesuai materi yang dibelajarkan pada masing-masing siklus. Tes pilihan ganda disertai empat alternatif jawaban yang dipilih oleh siswa. Setiap jawaban yang benar mendapat skor satu (1) dan skor nol (0) untuk jawaban siswa yang salah. Untuk soal isian, jawaban benar diberikan skor dua (2), jawaban kurang tepat diberikan skor satu (1), dan skor nol (0) jika siswa tidak menjawab atau jawabannya salah. Skor yang diperoleh siswa tersebut dikonversikan menjadi nilai menggunakan rumus :

$$
\text { Nilai }=\frac{\text { Skorperolehan }}{\text { Skormaksimum }} \times 100
$$

Teknik analisis data yang digunakan dalam penelitian inidianalisis dengan statistik deskriptif, yaitu dengan menghitung skor rata-rata kelas $(\bar{X})$ dengan rumus sebagai berikut.

$$
\bar{X}=\frac{\sum_{i=1}^{n} X_{i}}{n}
$$

Keterangan :

$\bar{X}=$ rata-rata skor prestasi belajar IPA siswa

$X_{i}=$ skor prestasi belajar IPA siswa

$n \quad=$ banyaknya siswa 
Kriteria keberhasilan: model pembelajaran kooperatif STAD dikatakan dapat untuk meningkatkan prestasi belajar IPA jikaketuntasan klasikal $\geq 85 \%$ berdasarkan KKM 70,00.

\section{HASIL PENELITIAN DAN PEMBAHASAN}

Pada siklus-1 dilakukan kegiatan pembelajaran empat kali pertemuan tatap muka dengan alokasi waktu dua jam pelajaran (2 x 40 menit). Materi yang dibelajarkan pada setiap pertemuan yaitu : (1) perkembangbiakan vegetatif pada tumbuhan, (2) perkembangbiakan generatif pada tumbuhan, perkembangbiakan vegetatif pada hewan, dan (4) perkembangbiakan generatif pada hewan. Hasil pengamatan atau observasi kegiatan belajar siswa pada pertemuan pertama kegiatan belajar siswa baik secara individual maupun sebagai anggota kelompok belum efektif karena siswa belum memahami tugas belajar yang dilakukan sesuai tahapan model pembelajaran kooperatif STAD. Masingmasing siswa melakukan kegiatan belajar sendiri-sendiri belum terjadi learning community. Sedangkan hasil kerja kelompok didominasi oleh siswa yang lebih pandai pada masing-masing kelompok demikian juga pada presentasi hasil kerja kelompok.Upaya yang dilakukan agar semua siswa dalam kelompok berperan aktif dalam kegiatan belajar kelompok, pada awal pertemuan pembelajaran ditekankan kembali tentang kegiatan belajar yang dilakukan sesuai tahapan model koopertaif STAD dan pembagian tugas belajar secara proporsional pada masingmasing anggota kelompok. Secara bertahap, kegiatan belajar siswa sudah mengacu pada tahapan kooperatif STAD meskipun tetap diarahkan terutama pada saat melakukan elaborasi dalam membuat laporan hasil kerja kelompok dan mempresentasikan hasil kerja kelompok.

Pada siklus-2 dilakukan kegiatan pembelajaran tiga kali pertemuan tatap muka dengan alokasi waktu dua jam pelajaran (2 x 40 menit). Materi yang dibelajarkan pada setiap pertemuan yaitu : (1) Adaptasi pada hewan, (2) Adaptasi pada tumbuhan, dan (3) Seleksi alam.Secara umum kegiatan belajar pada siklus-2, semua kelompok sudah mampu melakukan tugas-tugas belajar sesuai tahapan 
model pembelajaran kooperatif STAD, setiap tahapan belajar diwarnai dengan diskusi kelompok. Efektifnya kegiatan belajar siswa berdampak pada peningkatan pencapaian prestasi belajar IPA. Perkembangan pencapaian prestasi belajar IPA siswa disajikan pada tabel berikut ini.

Tabel 1

Perkembangan Prestasi belajar IPA Siswa

\begin{tabular}{|r|l|r|r|}
\hline \multirow{2}{*}{ No } & \multirow{2}{*}{ Prestasi belajar IPA } & \multicolumn{2}{|c|}{ Pencapaian } \\
\cline { 3 - 4 } & & 60,00 & \multicolumn{1}{|c|}{ Siklus-2 } \\
\hline \hline 1 & Nilai terendah & 90,00 & 60,00 \\
\hline 2 & Nilai tertinggi & 76,30 & 95,00 \\
\hline 3 & Rata-rata kelas & $81,48 \%(22$ siswa) & $88,89 \%(24$ siswa) \\
\hline 4 & Siswa yang tuntas & $18,52 \%(5$ siswa) & $11,11 \%(3$ siswa) \\
\hline 5 & Siswa yang tidak tuntas & & \\
\hline
\end{tabular}

Penerapan model pembelajaran kooperatif STAD dalam pembelajaran mata pelajaran IPA khususnya standar kompetensi "Kelangsungan Hidup Organisme" di kelas IX-B SMP Negeri 4 Banjar semester ganjil tahun pelajaran 2015/2016 secara bertahap mampu memfasilitasi kegiatan belajar berpusat pada siswa. Pada pembelajaran prasiklus pencapaian ketuntasan klasikal 66,67\% dan meningkat setelah diterapkan model pembelajaran kooperatif STAD dengan pencapaian ketuntasan klasikal $81,48 \%$ pada siklus-1 dan $88,89 \%$ pada siklus-2 berdasarkan KKM 70,00.

Pencapaian ketuntasan klasikal $81,48 \%$ pada siklus-1 belum mampu memenuhi kriteria keberhasilan penelitian yang ditentukan $\geq 85 \%$ berdasarkan KKM 70,00. Hal ini disebabkan belum terjadi kegiatan belajar secara efektif sesuai tahapan model pembelajaran kooperatif STAD. Pada pertemuan siklus-1, kegiatan belajar masih didominasi oleh siswa yang lebih pandai pada masingmasing kelompok dan hasil kerja kelompok belum mencerminan hasil pemikiran semua anggota kelompok. Untuk meningkatkan efektivitas belajar siswa, maka pada awal pertemuan kegiatan pembelajaran pertemuan kedua sampai dengan 
pertemuan keempat siklus-1 ditekankan kembali tugas-tugas belajar yang harus dilakukan dan pentingnya kerja sama dalam belajar. Selama kegiatan belajar berlangsung dilakukan pendampingan pada setiap kelompok untuk mengetahui permasalahan belajar yang dihadapi siswa sehingga bantuan belajar dapat diberikan dengan segera serta sesuai kebutuhan belajarnya.

Kegiatan belajar pada siklus-2 sudah mulai efektif sesuai tahapan model pembelajaran kooperatif STAD. Semua anggota masing-masing kelompok sudah mampu melakukan kegiatan belajar secara proporsional sesuai tugas belajar yang menjadi tanggung jawabnya. Pada setiap tahapan belajar dilakukan melalui diskusi, baik dalam menentukan informasi atau materi yang digunakan dalam menyelesaikan permasalahan-permasalahan pada LKS dan juga dalam melakukan presentasi hasil kerja kelompok. Kegiatan belajar siswa pada siklus-2 sudah efektif yang berdampak pada pencapaian prestasi belajar IPA yang optimal dengan ketuntasan klasikal 88,89\%. Peningkatan pencapaian ketuntasan klasikal ini sesuai dengan hipotesis tindakan yang diajukan, yaitu ada peningkatan prestasi belajar IPA khususnya standar kompetensi "Kelangsungan Hidup Organisme" siswa kelas IX-B SMP Negeri 4 Banjar semester ganjil tahun pelajaran 2015/2016 melalui penerapan model pembelajaran kooperatif STAD". Hasil penelitian ini sesuai dengan hasil penelitian yang dilaksanakan Warta, 2011 ; Sedana, 2015 ; dan Marliana, dkk. yang menyimpulkan bahwa penerapan model pembelajaran kooperatif STAD dapat meningkatkan prestasi belajar IPA siswa.

Kegiatan belajar yang dirancang melalui pembelajaran kooperatif STAD memberikan peluang kepada siswa untuk meningkatkan berbagai keterampilan, diantaranya keterampilan berpikir kritis, menemukan, mengevaluasi, bekerja sama dalam tim, dan menggunakan sumber yang tepat. Pemilihan model pembelajaran yang tepat sesuai dengan permasalahan pembelajaran sangat dibutuhkan kemampuan guru melakukan analisis dan refleksi. Tidak semua permasalahan pembelajaran bisa diatasi dengan model yang sama, meskipun ada kesamaan permasalahan. Internalisasi materi yang dibelajarkan menjadi lebih optimal karena tahapan pembelajaran kooperatif STAD mampu memfasilitasi kegiatan pembelajaran yang berpusat pada siswa. Proses pengkonstruksian terjadi karena 
siswa difasilitasi melakukan hubungan atau mengasosiasikan antara pengetahuan atau keterampilan yang telah dimiliki dengan pengetahuan atau keterampilan baru yang dibelajarkan. Karena siswa bersifat "unik", maka guru dalam pembelajaran lebih berperan sebagai mediator dan fasilitator sehingga siswa belajar dengan cara dan gayanya masing-masing. Peningkatan prestasi belajar IPA siswa tersebut karena siswa dalam mengkonstruksi pengetahuan melalui proses berpikir secara kolaboratifmelalui kegiatandiskusi, tanya jawab dan presentasi. Adanya penghargaan kelompok setiap pertemuan (tatap muka) menjadi salah satu motivasi siswa untuk melakukan kegiatan belajar. Model pembelajaran kooperatif STAD memberikan kesempatan kepada siswa untuk lebih aktif dalam mengkonstruksi pengetahuan atau keterampilan baru di dalam struktur kognitifnya sehingga terjadi proses belajar bermakna.

Melalui rangkian kegiatan pembelajaran seperti tersebut di atas, maka pengetahuan yang diperoleh siswa dalam belajar berdasarkan hasil kegiatan aktif dengan cara mereka masing-masing, guru hanya berperan sebagai pembimbing, fasilitator, dan pendukung, artinya guru bukan lagi berperan sebagai sumber informasi dalam pembelajaran. Belajar bermakna (meaningful learning) adalah suatu proses belajar dimana informasi baru dihubungkan dengan struktur pengertian yang sudah dipunyai seseorang yang sedang belajar. Belajar bermakna terjadi bila pelajar mencoba menghubungkan fenomena baru kedalam struktur pengetahuan mereka, dan hal ini terjadi pada siswa karena mereka belajar dengan cara mereka tanpa harus duduk manis mendengar kata-kata yang diucapkan guru.

Model kooperatif STAD berdampak poistif terhadap proses dan penguasaan konsep atau kompetensi yang dibelajarkan karena dalam belajar siswa menerapkan prinsip dasar dalam pembelajaran kooperatif (Ibrahim dkk, 2000 : 16), yaitu : (1) setiap anggota kelompok bertanggung jawab atas segala sesuatu yang dikerjakan dalam kelompoknya, (2) setiap anggota kelompok memahami bahwa semua anggota kelompok mempunyai tujuan yang sama, (3) siswa menyadari bahwa setiap anggota kelompok mempunyai tugas dan tanggung jawab yang sama diantara anggota kelompoknya, (4) siswa memahami setiap anggota kelompok akan dievaluasi, (5) setiap anggota kelompok mampu sebagai 
pemimpin kelompok dan memiliki keterampilan belajar kelompok (learning community). Membangun pengetahuan didasarkan kepada dua asumsi yaitu :asumsi pertama adalah perolehan pengetahuan merupakan suatu proses interaktif yaitu siswa yang belajar akan berinteraksi dengan lingkungannya secara aktif, perubahan tidak hanya terjadi dilingkungan tetapi juga dalam diri siswa itu sendiri. Asumsi kedua adalah siswa yang mengkonstruksi pengetahuannya dengan menghubungkan informasi yang masuk dengan informasi yang tersimpan yang diperoleh sebelumnya.

Kegiatan belajar siswa menjadi lebih efektif karena siswa dalam belajar tidak terpaku pada penyampaian informasi oleh guru namun siswa secara kolaboratif mencari tahu kebutuhan belajar mereka sehingga dengan sendirinya juga terjadi interaksi sosial yang lebih optimal. Hal ini sesuai dengan kelebihan model pembelajaran kooperatif STAD sebagaimana diuraikan oleh Slavin, 1995 (Rusman, 2013 : 205) yaitu : (1) penggunaan pembelajaran kooperatif STAD dapat meningkatkan prestasi belajar siswa sekaligus dapat meningkatkan hubungan sosial, menumbuhkan sikap toleransi, dan menghargai pendapat orang lain, dan (2) pembelajaran kooperatif dapat memenuhi kebutuhan siswa dalam berpikir kritis, memecahkan masalah, dan menginterprestasikan pengetahuan dan pengalaman. Belajar secara kolaboratif memfasilitasi siswa belajar secara gotong royong dalam menyelesaikan permasalahan/tugas belajarnya yang disertai proses diskusi dan adu argumen sehingga kompetensi yang dipelajari terkonstruksi secara bermakna dalam struktur kognitifnya sesuai potensinya masing-masing.

\section{PENUTUP}

\subsection{Kesimpulan}

Berdasarkan hasil analisis data penelitian dan pembahasan yang diuraikan di atas dapat disimpulkan bahwa, penerapan model pembelajaran kooperatif STAD dapat meningkatkan prestasi belajar IPA khususnya pada standar kompetensi "Kelangsungan hidup organisme" siswakelas IX-B SMP Negeri 4 Banjar semester ganjil tahun pelajaran 2015/2016. 


\subsection{Saran}

Saran-saran yang dapat disampaikan sesuai hasil penelitian tindakan kelas ini yaitu:

1. bagi para guru agar keberhasilan penelitian ini dijadikan salah satu rujukan untuk meningkatkan prestasi belajar IPA mata pelajaran IPA pada jenjang SMP,

2. bagi pihak lain agar melakukan penelitian sejenis dengan kajian pada subjek dan objek yang berbeda, dan

3. bagi pemegang kebijakan, agar mengapresiasi dan memfasilitasi kegiatan inovasi pembelajaran yang dilakukan melalui penelitian tindakan kelas.

\section{DAFTAR PUSTAKA}

Depdiknas. 2008. Pengolahan dan Analisis Data Penelitian. Jakarta : Direktorat Tenaga Kependidikan Direktorat Jenderal Peningkatan Mutu Pendidik dan Tenaga Kependidikan Departemen Pendidikan Nasional.

Dimyati dan Mudjiono. 2009. Belajar dan Pembelajaran . Jakarta: Rineka Cipta.

Marliana, dkk. 2015. Pengaruh Model Pembelajaran Kooperatif Tipe STAD Berbantuan Multimedia Pembelajaran Interaktif Terhadap Prestasi belajar IPA IPA. e-Journal Edutech Universitas Pendidikan Ganesha Jurusan Teknologi Pendidikan (Vol: 3 No: 1 Tahun: 2015).

Muslimin, Ibrahim, dk. 2000. Pembelajaran Kooperatif. Surabaya : University. Purwanto, Ngalim. 2010. Psikologi Pendidikan.Bandung : Remaja Rosda Karya

Riyanto, Yatim. 2012. Paradigma Baru Pembelajaran. Jakarta : Kencana Prenada Media Group.

Rusman. 2013. Model-Model Pembelajaran : Mengembangkan Profesionalisme Guru. Edisi Kedua. Jakarta : Raja Grafindo Persada.

Sanjaya, Wina. 2013. Penelitian Tindakan Kelas. Jakarta : Kencana Prenadana Media Group. 
Sedana, I Gede Ketut. 2015. Peningkatan Aktivitas dan Prestasi belajar IPA Biologi Siswa SMP dengan Model Kooperatif Tipe STAD. Jurnal IlmuIlmu Pendidikan IKIP Saraswati Tabanan Volume 13 Nomor 2 Desember 2015. ISSN : 1829-894X.

Sucipta, I Putu dkk. 2014. Implementasi Kooperatif STADuntuk Meningkatkan Aktivitas dan Prestasi belajar IPAPassing Bola Basket. E-Journal PJKR Universitas Pendidikan Ganesha Jurusan Pendidikan Jasmani Kesehatan dan Rekreasi (Vol 2 Tahun 2014).

Sudjana, Nana. 2010. Dasar-dasar Proses Belajar. Bandung : Sinar Baru.

Sugiyanto. 2010. Model-Model Pembelajaran Inovatif. Surakarta : Yama Pustaka.

Trianto. 2010. Model Pembelajaran Terpadu dalam Teori dan Praktek. Jakarta : Prestasi Pustaka.

Warta, Nyoman. 2011. Penerapan Model Guided Inquiry melalui Setting Pembelajaran Kooperatif STAD dalam Pembelajaran IPA. Jurnal Pendidikan Kabupaten Buleleng Kerta Mandala Volume 1 Nomor 3, Oktober 2011. ISSN : 2085-9716. 